\title{
Health-seeking behavior of migrant beggars in Ibadan, Southwestern Nigeria
}

\author{
Kabiru K. Salami", Aishat O. Olugbayo \\ Department of Sociology, University of Ibadan, Ibadan, Nigeria; ${ }^{*}$ Corresponding Author: kabsalami@yahoo.co.uk
}

Received 23 February 2013; revised 26 March 2013; accepted 9 April 2013

Copyright (c) 2013 Kabiru K. Salami, Aishat O. Olugbayo. This is an open access article distributed under the Creative Commons Attribution License, which permits unrestricted use, distribution, and reproduction in any medium, provided the original work is properly cited.

\begin{abstract}
Most studies on beggars in Nigeria have focused exclusively on the social course of indigenous begging activities in Nigerian cities. There exists dearth of knowledge about international migrant beggars and their health-seeking behavior in Ibadan Southwestern Nigeria. A cross sectional survey data were collected through purposive sampling technique among a total of 250 international migrant beggars in six locations in Ibadan. Results showed that $56 \%$ of respondents were female, few had formal education, $\mathbf{8 5 . 6 \%}$ were married, and $\mathbf{9 4 . 8 \%}$ were Muslim. Respondents migrated from Niger (83.6\%), Chad (11.2\%), Mali (4.0\%) and Benin (1.2\%). None had a legal residence permit. Respondents' mean residence duration in Nigeria was 8.5 years. Malaria was common to beggars both in their home country and in Nigeria. Treatment was received from patent medicine vendors by $51.2 \%$ respondents. Advice for appropriate treatment for illness was received from family members by $44.4 \%$ migrant beggars. Sex and country of beggars have a direct relationship with the treatment seeking $(P<0.05)$. Financial and legal status of migrant beggars dynamically limited their healthcare choices. Routine health education on hygiene practice and appropriate treatment-seeking should be taken to beggars at their different locations by health workers as means of prevention of the spread of diseases.
\end{abstract}

Keywords: Begging; Health-Seeking Behavior; Migrant Beggar; Migration; Nigeria; Treatment

\section{INTRODUCTION}

The rate at which people are becoming involved in begging activities is increasing in Africa. The incidence of such rates may be partly due to inequitable distribution of scarce resources [1], and economic hardship and meltdown [2] among others that make the poor people to be poorer in resource-poor nations. Although not all poor people face the same risks, the diversity of vulnerability factors existing in different social contexts determines the solution [3] that people seek. Begging was considered a solution for some people to arrest poverty [4]. People also migrate outside their home community to gain independence [5] from disabling diseases like leprosy [6], for avoidance of natural disasters like war, famine, drought and other man-made challenges [7] like political instability and for greener pastures-economic factors [2]. Regassa and Yusufe documented the untold immense contribution of migration to social mobility, socioeconomic development of both individuals and the nation [8], and provision of career opportunities are not accessible or even denied at home. Conversely, migration has its own inertia by creating gender-based violence; sexual harassment and exploitation; discrimination; and the task of combining childbearing and work outside the home among others $[9,10]$. The challenge is compounded when an individual migrates not even to other zones of their own countries but to other countries.

One challenge related to the theme of this study is that migrants face more risk of developing and/or spreading infections. For instance, TB was found more frequent in excluded groups such as amazonic indigenous populations [11] and migrants from developing countries [12, 13]. Likewise population displacement, migration and human suffering caused by war and natural disasters were found to influence the malaria transmission and control in multiple ways [14]. Another challenge that migrants face is the low access to health facilities in their places of destination [1]. These, together heightened by the socio-cultural barriers and language problem, make diagnosis and treatment very difficult to access [15-17]. Even in spite of limited access, both receipts of care and affordability of services declined with socioeconomic 
status [18-20]. Migrants just like refugees are identified as a particularly challenged and highly marginalised community, experiencing multiple disadvantages such as poor education, economic and social vulnerability [21, 22]. In Nepal, Kirwan et al. [22] noted that due to crowded living conditions, poor access to resources and poor nutrition, migrants suffer disproportionately from infectious diseases of poverty, particularly TB infections, as in urban settings of many other countries.

While migration poses some challenges, it also serves as a major component of population change and development [23]. Afolayan, et al. [24] theorised that the decision to move out of a location is often based on the socio-economic inadequacies that exist in the source region with "push" endogenous factors (such as unemployment, dearth of socioeconomic, poverty, etc.) to destinations with attractive "pull" exogenous factors of employment opportunities, accessibility and availability of socio-economic facilities, and better life generally. What is infiltrating particular challenge to health and development is the increasing rate of international migrants to Nigeria as beggars, not as immigrants who might contribute to the economy and development. Studies have noted that locations in zones of the jungle as geographic barriers, make difficult the access to basic services and health facilities. These characteristics, often attributed to migrants together with geographic dispersion, poor access to basic services such as water, drains, and roads, make them vulnerable to the development of infectious diseases [7,25] especially hepatitis B [26], TB [11] and malaria [27]. Possession of these characteristics by migrant beggars [2,7] with limited access to basic amenities [15-17] in poor-resourced nations impact on their health, hence need to profile their health-seeking behavior in a resource-poor setting.

\section{Characteristics of Begging in Nigeria}

Begging as a "profession" has attracted the attention of scientists [28-31] and governments of advanced countries of the world [31]. Beggars pervade public places; like market, motor parks, religious centres and traffic junctions [32]; commercial centers; residential neighbourhood [33]; campuses of tertiary institutions and inside buses [34]. Jelili [34] observed that begging reaches its weekly peak on Fridays. The current socio-economic realities giving rise to extreme poverty in Nigeria [33] perpetuate begging among other factors. Ribadu and Mahmoud [33] reported that over three-quarters of their respondents (street beggars) had no access to any form of welfare supports and health services.

Although increasing academic attention has been directed to the menace of domestic begging [4,29,31], there exists dearth of knowledge on the health-seeking behaviour of beggars. Beggars are found in all societies; the most common ones in Nigeria, for instance, are indigenous/domestic beggars than the foreigners who operate in another country different from theirs. The main focus of this study is international migrant beggars. They are (usually) physically able bodied persons different from physically disabled that constitute the bulk of domestic beggars [31]. Based on Rosenstock's Health Belief Model that is concerned with the subjective view of the individual on prior health experiences [35-37], the perception of migrant beggars about their health status was assumed to affect the nature of help they seek for improving, maintaining and sustaining their status. Likewise the belief that migrant beggars are susceptible to certain health problems encourages or discourages behaviors that are health-promoting. This study was mainly designed to profile the health-seeking behavior of the international migrant beggars in Ibadan Nigeria. Another effort was to create a further study-demand in this area of research; migrant beggars form a formidable rate in the entire beggar population in Nigerian cities, yet there is dearth of knowledge about health-seeking behavior of the group in literature.

\section{METHOD}

\subsection{Research Design}

This exploratory research was cross sectional in Ibadan Nigeria, and sought health-seeking behavior information among international migrant beggars in 2009. Although there is no restriction of locations for beggars, migrant beggars are mostly found in focal points/places usually near major motor parks, major markets and major junctions in the city. There might be slightly over 20 begging focal points in Ibadan comprising major parks, major markets and major junctions. The six locations considered in this study; spread/cut across the city, popular in terms of population and frequency, also central to locations where people reach for daily business and activities, and finally possess at least two of focal points criteria (e.g. major markets, major motor parks and major junctions). A purposive sampling technique generated 250 sampled beggars who were traced to their locations at major motor parks, major markets, and major junctions, in Bodija, Ojo, Beere, Sabo, Agodi-gate, and tollgate Ibadan. Interviewers set out in the morning to trace the migrant beggars to their respective locations.

\subsection{The Setting}

This study was carried out in Ibadan, the city which had an estimated population of 2,550,593 according to the 2006 population census, and as at time of study, which comprises 11 local government areas (LGAs). The population of central Ibadan that makes up five LGAs 
was 1,338,659. Among the different institutions located in the city of Ibadan include hospitals (such as University College Hospital, Adeoyo Maternity Hospital, Jericho homes, and several private hospitals), total institutions (such as police station, prison, law courts), major markets (such as Bodija Market, Oja’ba market, Gbagi market, Dugbe market, Bere market, Sango market, Ojoo market, and Bashorun market among others), Non-governmental organizations which focus on family and reproductive health, safety practices, environmental health and so on. Although there are pharmacies stores in the heart of the city and sometimes located not too far from government hospitals, there also exist patent medicine vendours (PMVs) at every not-distant locations in the streets. Indigenous healers also have their shops spread aross the city while most markets provide stalls for those that are market-based.

\subsection{Field Process}

Primary data were generated with the use of a questionnaire. The questionnaire was designed with four subsections that addressed the socio-demographics of respondents, illness experiences, treatment options and utilization of services and their social networking process. Three field assistants were trained and involved in the data collection. The field assistants were supervised by one of the researchers.

\subsection{Sampling Size and Technique}

Sampling was purposive and targeted at respondents whose age was not less than 16 years in the selected six locations where samples were drawn. On arrival at each location, all the 3 field assistants were made to work together in the same location; facing different directions/ sections until the location is exhausted before they moved to another location. During the training of field assistants, clarifications about criteria for distinguishing international beggars from domestics ones were drawn. One key feature is the colour of the skin of the international beggars which is not dark like the Nigerians. This criterion was used to trace respondents. Overall, 250 respondents whose ages were within the target population were surveyed.

\subsection{Consents}

Verbal consent was sought from participants before questionnaire was administered for maximum time of forty-five minutes per respondent. Majority of migrant beggars spoke Yoruba, the local language of the study community. Most respondents also spoke "pidgin” English. Where a respondent could not speak either the local language or 'pidgin' English, effort was made to locate one migrant beggar who speak either the local language or "pidgin" English and can interpret for both the respondent and the interviewer. In spite of this effort, some respondents refused interview completely while some respondents broke out of the interview half way. Language barrier however still remains a major limitation in the study as there were some beggars who could not be communicated with at all and field assistants had to move on to the next one.

\subsection{Data Management and Analysis}

All completed administered questionnaires were edited on daily basis to ascertain validity and reliability of information. All the field assistants and the supervisor shared their experiences daily. At the end of data collection, uncompleted questionnaires were exempted from analysis. All completed data were cleaned and open ended questions were coded and entered into the computer for analysis with the use of Statistical Package for Social Sciences (SPSS). The study utilised quantitative analysis tools such as percentages and frequencies and chi-square statistical method for making inferences.

\section{FINDINGS}

Overall, 250 international migrant beggars were traced and made to participate in this survey. The age of respondents ranged between 16 and 55 years of which the majority (58.4\%) were between the ages of 20 and 29 years, with modal age as 20 years in the population. Respondents aged 50+ years had the lowest frequency (2.8\%) and the mean age for the age range of all respondents was 26.6 years. Table 1 indicates that the dependent age group accounts for $2.8 \%$ while more than half (56\%) of total respondents were females. Data also reveal that $52 \%$ of the migrant beggars had Arabic education than primary education (9.6\%). Five $(2.0 \%)$ beggars had reportedly undergone tertiary education. The study shows that more than three-quarter $(85.6 \%)$ of respondents were married, very few were single (13.2\%) while $1.2 \%$ of them were divorced as at time of survey. Results reveal that about $94.8 \%$ of the respondents were Muslims than followers of Christianity (2.8\%) and indigenous religious beliefs (0.4\%).

Respondents reported their parity. Most (62.2\%) had one to three children, others had: 4 - 6 children (30.6\%); 7 - 9 children (5.9\%); and 10 - 12 children (1.4\%). Result also shows that the mean number of children of the respondents was four and sex distribution of these children was 96 reportedly boys and 126 girls. Results also indicate that majority (48.8\%) of the respondents had no sex preference, $27.2 \%$ preferred female child and $18.4 \%$ respondents preferred male child. About 5.6\% did not respond to the question. Figure 1 indicates that most $(83.6 \%)$ of the respondents were Nigeriens while least 
Table 1. Socio-demographic characteristics of respondents.

\begin{tabular}{lll}
\hline Age & Frequency & Percent \\
\hline $10-19$ & 38 & 15.2 \\
$20-29$ & 146 & 58.4 \\
$30-39$ & 39 & 15.6 \\
$40-49$ & 22 & 8.8 \\
50 and above & 5 & 2.8 \\
Total & 250 & 100 \\
Sex & Frequency & Percent \\
Male & 110 & 44.0 \\
Female & 140 & 56.0 \\
Total & 250 & 100 \\
Level of education & Frequency & Percent \\
None & 85 & 34.0 \\
Arabic & 130 & 52.0 \\
Primary & 24 & 9.6 \\
Secondary & 2 & 0.8 \\
Tertiary & 5 & 2.0 \\
No response & 4 & 1.6 \\
Total & 250 & 100 \\
\hline
\end{tabular}

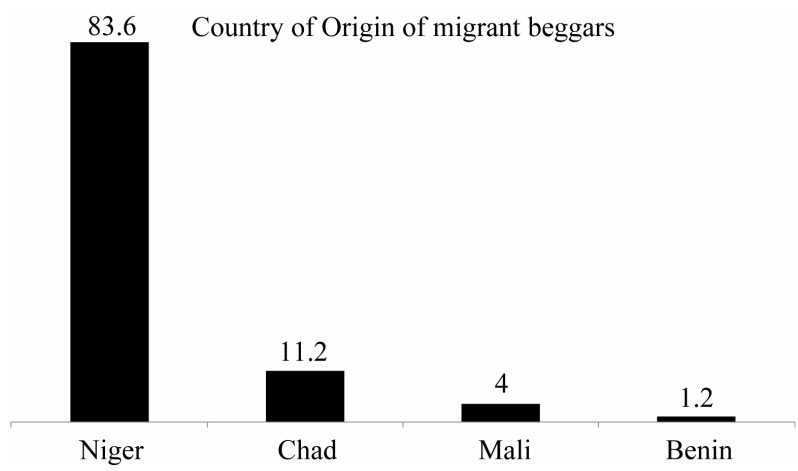

Figure 1. Country of origin of migrant beggars.

(1.2\%) were from Benin.

Table 2 shows the ethnic distribution of migrant beggars. In all, respondents from Mali and Niger, respectively, accounted for four ethnic groups each, while those from Chad and Benin respectively accounted for three ethnic groups each. Migrant beggars from Tarwa ethnic group in Niger conveniently accounted for about half (43.6\%) total migrant population.

Although none of the beggars surveyed reportedly had legal residence permit, this study sought information about their residence duration. The residential duration of migrant beggars ranged between one and twenty-nine years in Ibadan. More than half (59\%) respondents were within their first and ninth years, others have spent between 10 and 19 years (33.3\%), and between 20 and 29 years $(7.6 \%)$ respectively. The result also shows that the
Table 2. Ethnic group of respondents.

\begin{tabular}{cccc}
\hline Country & Ethnic groups & Frequency & Percent \\
\hline \multirow{3}{*}{ Mali } & Arab & 26 & 10.4 \\
& Soninke & 3 & 1.2 \\
& Sara & 7 & 2.8 \\
& Tuareq & 3 & 1.2 \\
\multirow{4}{*}{ Niger } & Hausa & 59 & 23.6 \\
& Massa & 2 & 0.8 \\
& Maambaye & 1 & 0.4 \\
& Tarwa & 109 & 43.6 \\
& Mande & 3 & 1.2 \\
& Malinke & 1 & 0.4 \\
& Toubou & 3 & 1.2 \\
& Dahomey & 2 & 0.8 \\
& Bariba & 1 & 0.4 \\
& Zabaruwa & 9 & 3.6 \\
& No response & 21 & 8.4 \\
& Total & $\mathbf{2 5 0}$ & $\mathbf{1 0 0}$ \\
\hline
\end{tabular}

mean number of years spent in Nigeria (host country) was 8.5 years. Less than half (42.8\%) respondents make a living by pure begging, while others involve in other activities like trading (28.4\%) and Artisan (24.4\%) in addition to begging. Respondents reported that they got to Nigeria in between the years 1981 and 2009. Table 3 depicts that significant numbers of the respondents (51.6\%) arrived Nigeria in between the year 2001 and 2008.

\subsection{Illness Experience of Beggars}

Respondents' report about their illness experiences revealed that six illnesses were most common to the migrant beggars both in Nigeria and their home countries. Figure 2 highlights migrant beggars' illness experiences and their comparisons by locations. Malaria was reportedly common to $44.4 \%$ and $44.0 \%$ respondents in Nigeria and their home countries respectively. Next was typhoid which was experienced more $(26.8 \%)$ in Nigeria than the $24.8 \%$ who had it in their home countries. Ulcer was mentioned also as part of illness they had in Nigeria (19.2\%) and their home countries (17.6\%). Others illnesses such as dizziness $(0.8 \%)$, headache $(0.8 \%)$, and asthma $(6.8 \%)$ were found to be common in their illness experience at home country than in Nigeria. Beggars reported that their illnesses were confirmed by competent health workers.

\subsection{Respondents' Illness Experience and Perceived Seriousness}

Slightly above a quarter (28.8\%) respondents reportedly had health problem. Among this category, fourteen 
Table 3. Years of arrival, residence duration and occupation of respondents in Nigeria.

\begin{tabular}{lcc}
\hline Year of arrival in Nigeria & Frequency & Percent \\
\hline $1981-1990$ & 21 & 8.5 \\
$1991-2000$ & 99 & 39.9 \\
$2001-2008$ & 128 & 51.6 \\
No response & 2 & 0.8 \\
Total & 250 & 100 \\
Residence duration in the Community & Frequency & Percent \\
1 - 9 years & 147 & 59.0 \\
10 - 19 years & 83 & 33.3 \\
20 - 29 years & 19 & 7.6 \\
No response & 2 & 0.8 \\
Total & 250 & 100 \\
What respondents do for living & Frequency & Percent \\
Begging alone & 107 & 42.8 \\
Trading with begging & 71 & 28.4 \\
Artisan with begging & 61 & 24.4 \\
No response & 11 & 4.4 \\
Total & 250 & 100 \\
\hline
\end{tabular}

(19.4\%) respondents indicated that they had "serious illness" for "affecting their body" (13.7\%), for being admitted in the hospital (1.4\%) and for being disturbed by the illness $(3.1 \%)$ on daily basis. The remaining respondents (80.6\%) reportedly felt weakened in the body but perceived their illnesses "not serious" for not disturbing their normal activities.

Results also show that more than half, 152 (60.8\%) respondents had health problems in the previous month before survey. About half (44.7\%) the respondents reported their health problems as malaria followed by $13.8 \%$ respondents who reported their health problem as typhoid and $6.7 \%$ as dizziness. Other illnesses reported are asthma (23.0\%), ulcer (10.5\%), and headache (3.9\%). About 39.2\% respondents indicated that they had health problem but could not be linked to specific illness. Slightly above three-quarter (76.0\%) of respondents noticed the "sign and symptoms" of their illness, among which are: shivering (40.4\%), vomiting (27.7\%), stomach upset (17.3\%) and other signs (12.6\%). Others signs included "hard breathing and high temperature" (Table 4). Others (2.0\%) did not notice the "signs and symptoms" while half each in this category felt that "it was not necessary for them to monitor the signs and symptoms of their health problems" and "I do not feel like

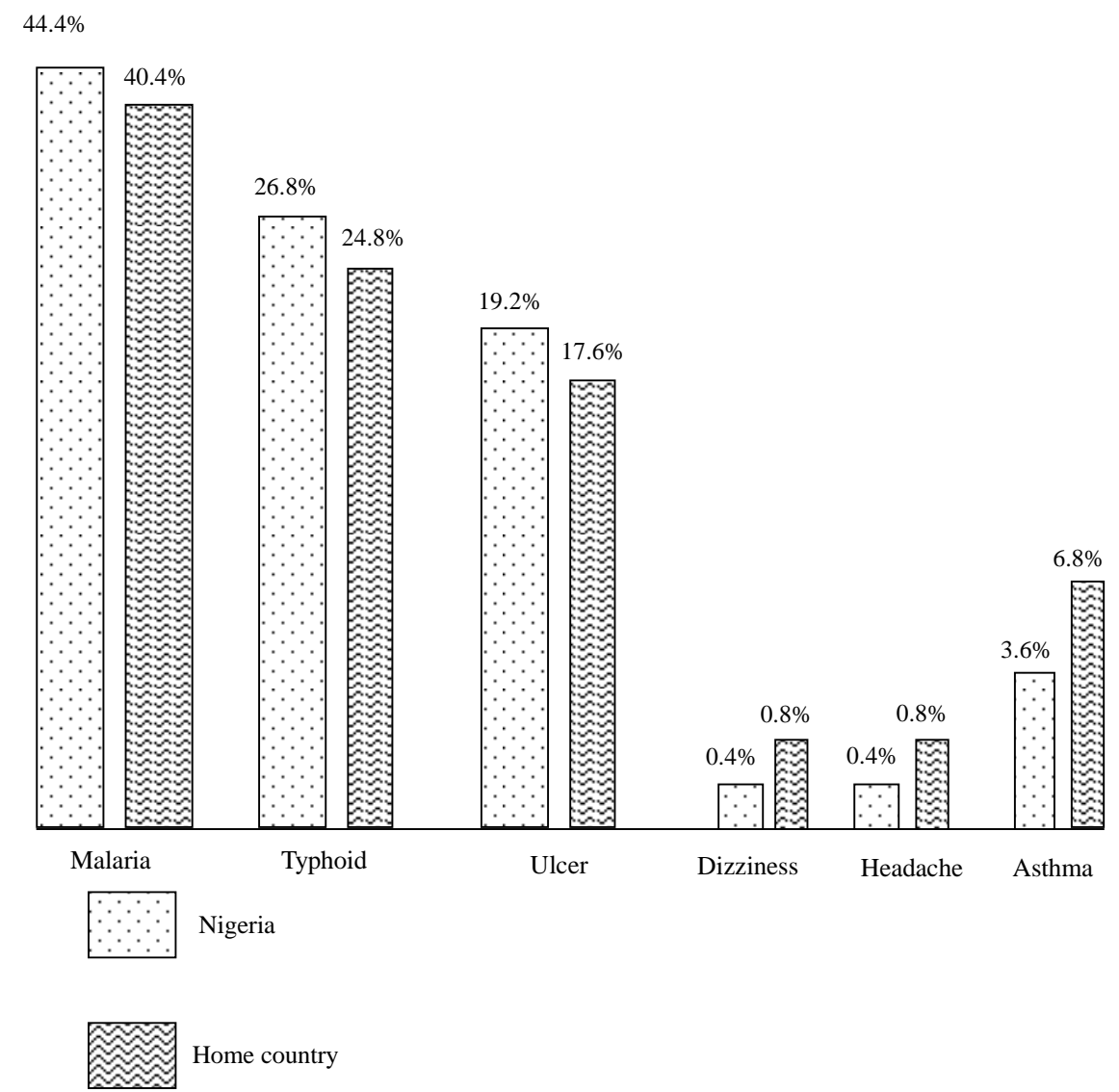

Figure 2. Illness experience of beggars in Nigeria and home country. 
Table 4. Respondents' perceived causes of ill health by the signs and symptoms.

\begin{tabular}{lccccc}
\hline \multirow{2}{*}{$\begin{array}{l}\text { Perceived factors responsible for the } \\
\text { ill health }\end{array}$} & \multicolumn{5}{c}{ Signs and Symptoms } \\
\cline { 2 - 6 } & Vomiting & Shivering & Stomach upset & Others $^{*}$ & Total \\
\hline Inadequate feeding & $6(15.8 \%)$ & $11(28.9 \%)$ & $15(39.5 \%)$ & $6(15.8 \%)$ & $38(100 \%)$ \\
Inadequate hygiene & $32(35.2 \%)$ & $33(36.3 \%)$ & $11(12.1 \%)$ & $14(15.4 \%)$ & $90(100 \%)$ \\
Dirty environment & $15(26.3 \%)$ & $32(56.1 \%)$ & $7(12.3 \%)$ & $3(5.3 \%)$ & $57(100 \%)$ \\
Eating much pepper & - & $2(66.7 \%)$ & - & $1(33.3 \%)$ & $3(100 \%)$ \\
Total & $53(27.7 \%)$ & $78(40.4 \%)$ & $33(17.3 \%)$ & $24(12.6 \%)$ & 188 \\
\hline
\end{tabular}

${ }^{*}$ Hard breathing and high temperature.

monitoring the signs and symptoms”.

Table 4 documents the perception of causes of illness. About half (44.5\%) of the respondents reported "inadequate hygiene" as what was responsible for their health problems, followed by $29.1 \%$ who reported "dirty environment" as being responsible for their health problems. Others were "inadequate feeding" (18.2\%), and "eating much pepper" (1.6\%). Nineteen respondents claimed "no response". Respondents reported one to 45 days as the time their problems started before survey. Large majority (95.1\%) had the problem started about half a month before survey, followed by three (1.5\%) and five (2.6\%) respondents who were within the range of 16 - 30 days and 31 - 45 days respectively. Slightly above a quarter (26.8\%) did not respond to this question.

Tracing family illness experience history, more (44.8\%) migrant beggars recalled that same health problems had occurred in their family back home than $8.9 \%$ beggars who could not recall. Other respondents never experienced such illness in their family. Poor hygiene (44.0\%), mosquito bite (29.2\%), exposure to coldness by sleeping outside (3.6\%) and inadequate feeding (2.8\%) were perceived as the main causes of their health problems by large majority than $20.4 \%$ without response.

The health-seeking behavior of beggars indicated that more than half $(69.6 \%)$ the respondents reportedly made an attempt to seek treatment to their health problems than 19 (7.6\%) who did not at all. Seventeen (6.8\%) beggars expressed that "it was not yet time for treatment". Others did not respond. The 19 beggars that did not attempt any treatment did so for such reasons as: "No money" (52.7\%), "illness perceived not serious" (15.8\%), and for having "faith" (5.3\%). Others (2.0\%) had no reason.

\subsection{Treatment Options and Utilization of Services}

Figure 3 shows the treatments used by the migrant beggars for illness experienced in Nigeria. It reveals that slightly more than half (51.2\%) the respondents obtained treatment from "chemist" followed by "health centers" (39.2\%) to treat their illnesses. Traditional healers were patronised by 17 (6.8\%) migrant beggars to obtain herbs

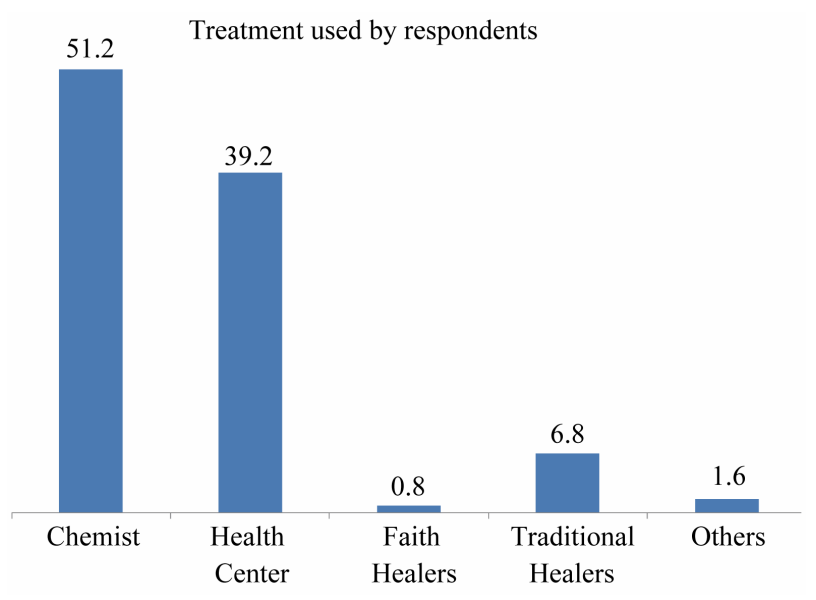

Figure 3. Treatments used by respondents.

for treatment.

The majority (55.8\%) of the respondents used the different treatments for being "less costly". Other reasons addressed included: proximity to where I live (20.5\%), free treatment offered (8.8\%), quality of service $(7.6 \%)$, availability of drugs (3.2\%), and positive and attractive attitudes of health workers (3.2\%). Three (1.2\%) beggars did not respond.

When emphasis was laid on more recent health facility used during the last illness episode in Nigeria, majority, 177 (70.8\%) reportedly visited orthodox health center with a large majority (97.2\%) of the users visited government hospitals, two (1.1\%) visited private clinic for treatment while three (1.65\%) respondents did not respond. Sources of information about the health facilities used during last illness episode were sought. Among others, "recommendation from people" was dominant with $81.9 \%$ followed by "information from radio" (9.6\%) and "seeing related information from billboards" (6.8\%). To this question, 76 (30.4\%) beggars did not respond.

Respondents were rated on their frequency of utilization of health facilities in their illness history. Three indicators were set: "often", "not often" and "rarely". Only $21.5 \%$ visited the health facility often, about $60 \%$ respondents did visit health center but not often, while $9.0 \%$ rarely visited health facility. For treatment sought, 
respondent reportedly paid between N150.00 and N 10000.00 with modal price of N1000.00 and mean price of N374.00. These funds were mostly raised/realized from: begging by 149 (72.2\%), income from other trade by 68 (38.4\%), support from other colleagues by 26 (14.7\%) and engaging in manual labour with spouse (husbands) by seven (4.0\%).

The 17 beggars that patronized traditional healers only obtained herbs for reasons that it was "less costly" (41.2\%), for being "quality" (35.3\%), "proximity to where we live" (17.6\%) and for "positive and attractive concerns of the healers" (5.9\%). More than half (58.8\%) beggars heard about the healers through friends, recommendations by others in the begging (35.3\%) and self exploration in town (5.9\%). About $47.1 \%$ of them visited the healers very frequently. Respondents reportedly paid between N50.00 and N1500.00 with mean price of N 406.00 for obtaining treatment. Majority of respondents were either somewhat satisfied (47.1\%) or highly satisfied $(23.5 \%)$ with the kind of treatment received from the alternative healers, than 5.9\% who were not satisfied. Another 5.9\% respondents were unable to identify level of satisfaction of use of alternative treatment. The main reasons for utilization were explained as: "quick effect" by seven (41.2\%), "less costly" by five (29.4\%), "it works well” by three (17.6\%) and "nearness to house” by two $(11.8 \%)$ respondents.

\subsection{The Social Networking among Migrant Beggars}

Majority (84.8\%) of beggars reported having relatives residing in Nigeria. More than half (59.2\%) of the respondents reportedly pooled and share money from same purse. Large majority (83.2\%) of respondents informed their relatives about their health status whenever they are ill. Advice to seek for treatment (44.4\%) was mostly received from relatives, followed by encouragement to go to hospital (23.6\%), financial and material promise (26.0\%) and none (4.8\%). Social support systems were mostly through emotional (42.0\%), financial (24.0\%), informational (17.6\%) and care (13.6\%). Other supports like giving attention, advice, and borrowing money when in need accounted for 2.0\% as shown in Figure 4.

The different kinds of problems faced by the beggars relating to ill social networking/interaction were identified. More than half, 138 (55.3\%) of the respondents reportedly had "misunderstanding relating with one another", also 10 (4.0\%) reported "gossiping and envy" while about seven (2.8\%) reported "problem of accommodation". Six (2.4\%) respondents reported "the lack of friendship" while "financial crisis/financial distrust problem” was reported by five (2.0\%) respondents.

Decision making process was reportedly: "self/per-

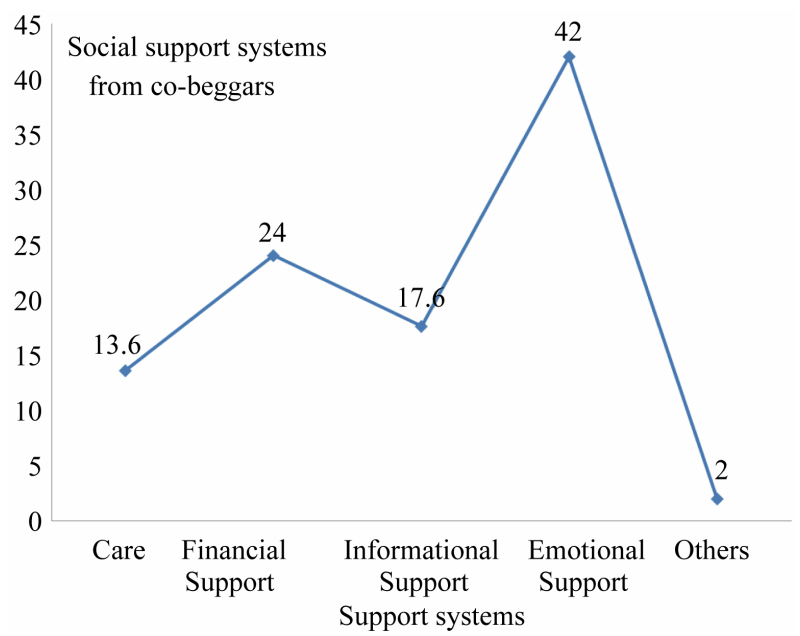

Figure 4. Social support systems from members of respondents.

sonal” by 139 (55.6\%), “spouse” by 93 (4.8\%), and "through others" by 12 (4.8\%). The final decision rests on the authority of "self/personal" by 119 (47.6\%), "spouse” by 108 (43.2\%) and “others" by 13 (5.2\%). Six (2.4\%) and $10(4.0 \%)$ respondents did not respond to the question of "initial decision process" and "final decisions" respectively.

On accessibility to treatment services, Table 5 shows detail reasons for the use of treatment according to facilities. PMV was mostly used by $51.2 \%$ followed by health center (39.2\%), and traditional healers (6.8\%). Respondents reportedly considered being "less costly" for making use of PMV (61.9\%) than other facilities. When proximity was a factor in making a choice, PMV (52.9\%) was also utilized. Table 5 also shows that $47.4 \%$ respondents who wanted quality service utilized health center. More than a quarter (37.5\%) respondents who were more concerned about the positive care/attention received from caregivers made use of traditional healers. Finally, the quest for free services $(61.9 \%)$ made respondents utilized health center for their illness.

Age, sex and level of education of respondents were tested with respondents' common illnesses. Table 6 indicates that malaria, typhoid and ulcer were common to male and female; all age categories; and across all educational status. Respondents within the age of 20 - 29 years were found to have suffered from all illnesses than other age groups. Respondents with Arabic education were found to have had more problems than respondents with other levels of education.

Table 7 provides detailed information about association between health seeking behavior factors and sex of beggars. The table contains the reasons for use of particular treatment by sex of respondents; reasons for use of specific modern health services; how beggars know about the treatment; and finally about how beggars raised 
Table 5. Accessibility patterns and choice/use of treatment by facilities.

\begin{tabular}{|c|c|c|c|c|c|c|}
\hline \multirow{2}{*}{$\begin{array}{l}\text { Factors encouraging used of } \\
\text { treatment (access) }\end{array}$} & \multicolumn{6}{|c|}{ Health Center Utilized } \\
\hline & Chemist/PMV & Health center & Faith healers & $\begin{array}{c}\text { Traditional } \\
\text { healers }\end{array}$ & Others & Total \\
\hline Less costly & $86(61.9 \%)$ & $47(33.8 \%)$ & - & $5(3.6 \%)$ & $1(0.7 \%)$ & $139(100 \%)$ \\
\hline Very close to where I live & 27 (52.9\%) & $21(41.2 \%)$ & - & $3(5.9 \%)$ & - & $51(100 \%)$ \\
\hline Its quality of service & $5(26.3 \%)$ & $9(47.4 \%)$ & - & $5(26.3 \%)$ & - & 19 (100\%) \\
\hline Health workers/carers show concern & $2(25.0 \%)$ & $2(25.0 \%)$ & - & $3(37.5 \%)$ & $1(12.5 \%)$ & $8(100 \%)$ \\
\hline Availability of drugs & $2(25.0 \%)$ & $5(62.5 \%)$ & - & - & $1(12.5 \%)$ & $8(100 \%)$ \\
\hline It is free & $6(24.2 \%)$ & $13(61.9 \%)$ & $2(9.5 \%)$ & $1(4.8 \%)$ & - & $22(100 \%)$ \\
\hline Total & $128(51.2 \%)$ & 98 (39.2\%) & $2(0.8 \%)$ & $17(6.8 \%)$ & $4(1.6 \%)$ & $250(100 \%)$ \\
\hline
\end{tabular}

Table 6. Respondents' common health problems by sex, age and level of education.

\begin{tabular}{|c|c|c|c|c|c|c|c|}
\hline \multicolumn{2}{|c|}{$\begin{array}{l}\text { Selected socio-demographic } \\
\text { structures/categories }\end{array}$} & \multicolumn{6}{|c|}{ Common health problems } \\
\hline Socio-demographic & Category & Malaria & Typhoid & Ulcer & Dizziness & Headache & Asthma \\
\hline \multirow{4}{*}{ Sex } & Male & $52(47.3)$ & $22(35.5)$ & $21(47.7)$ & - & $2(100.0)$ & $6(35.3)$ \\
\hline & Female & $58(52.7)$ & $40(64.5)$ & $23(52.3)$ & $2(100.0)$ & - & $11(64.7)$ \\
\hline & Total & 110 & 62 & 44 & 2 & 2 & 17 \\
\hline & $10-19$ yrs & 19 (17.3) & $9(14.5)$ & $6(13.6)$ & - & - & $3(17.6)$ \\
\hline \multirow{5}{*}{ Age } & $20-29$ yrs & $66(60.0)$ & $34(54.8)$ & 27 (61.4) & $2(100.0)$ & $1(50.0)$ & $10(58.8)$ \\
\hline & $30-39$ yrs & 12 (10.9) & $14(22.6)$ & $5(11.4)$ & - & - & $3(17.6)$ \\
\hline & $40-49$ yrs & $11(10.0)$ & $4(6.5)$ & $5(11.4)$ & - & $1(50.0)$ & $1(5.9)$ \\
\hline & $50 \mathrm{yrs}^{+}$ & $2(1.8)$ & $1(1.6)$ & $1(2.3)$ & - & - & - \\
\hline & Total & 110 & 62 & 44 & 2 & 2 & 17 \\
\hline \multirow{6}{*}{ Level of education } & None & $36(32.4)$ & $26(38.8)$ & 19 (39.6) & - & - & $2(16.7)$ \\
\hline & Arabic & $59(53.2)$ & 35 (52.2) & $20(41.7)$ & - & - & $9(75.0)$ \\
\hline & Primary & 13 (11.7) & $2(3.0)$ & $5(10.4)$ & $1(100.0)$ & $1(100.0)$ & $1(8.3)$ \\
\hline & Secondary & $2(1.8)$ & - & - & - & - & - \\
\hline & Tertiary & - & $2(3.0)$ & - & - & - & - \\
\hline & Total & 110 & 55 & 44 & 1 & 1 & 12 \\
\hline
\end{tabular}

fund for treatment. When relationship between reasons for use of treatment and gender were tested, more than average (57.0\%) beggars, overall, considered "cost of treatment" for its choice followed by "proximity to service" and "free service". When cost of health services is less costly, it is mostly used by female (62.7\%) than male (37.3\%). "Proximity to service areas" also prompted female beggars to utilise healthcare services than the male.

Majority of beggars got to know about the facilities they used based on recommendation of others (63.1\%) followed by information from radio programs and what they saw on billboards. More of men (60.8\%) who had main business, especially, were able to raise funds for their treatment than through begging by female (79.1\%). Findings (Table 7) indicate that the sex of respondents is directly related with; the reasons for use of treatment ( $\mathrm{P}$ $=0.03)$, the use of modern health facility $(P=0.001)$ : how beggars know about the facility they utilised $(\mathrm{P}=$ $0.000)$ and how they raise funds for the treatment $(\mathrm{P}=$ $0.000)$. Country of respondents was also found significant in the health-seeking behavior of migrant beggars. Table 8 shows that reasons for use of facility, reasons for use of modern health facility, how beggars know about treatment and means of raising funds for treatment; have 
Table 7. Health-seeking behavior factors associated with sex of beggars.

\begin{tabular}{|c|c|c|c|c|c|}
\hline \multirow{2}{*}{ Reasons for use of facility } & \multicolumn{3}{|c|}{ Sex } & \multirow{2}{*}{ Statistics } & \multirow{2}{*}{$P$ value } \\
\hline & Male $(\mathrm{N}=110)$ & Female $(\mathrm{N}=140)$ & Total $(\mathrm{N}=250)$ & & \\
\hline Less costly & $37.3 \%$ & $62.7 \%$ & 142 & \multirow{6}{*}{$\mathrm{X}^{2}=12.31$} & \multirow{6}{*}{0.030} \\
\hline Very close to where I live & $45.1 \%$ & $54.9 \%$ & 51 & & \\
\hline Its quality of services & $63.2 \%$ & $36.8 \%$ & 19 & & \\
\hline Health workers show concern & $87.5 \%$ & $12.5 \%$ & 8 & & \\
\hline Availability of drugs & $37.5 \%$ & $62.5 \%$ & 8 & & \\
\hline It is free & $57.1 \%$ & $42.9 \%$ & 22 & & \\
\hline Reasons for use of modern health services & Male $(\mathrm{N}=76)$ & Female $(\mathrm{N}=101)$ & Total $(\mathrm{N}=177)$ & Statistics & $P$ value \\
\hline Less costly & $26.6 \%$ & $73.4 \%$ & 79 & & \\
\hline Very close to where I live & $50.0 \%$ & $50.0 \%$ & 30 & \multirow{5}{*}{$X^{2}=20.35$} & \multirow{5}{*}{0.001} \\
\hline Its quality of services & $61.9 \%$ & $38.1 \%$ & 21 & & \\
\hline Health workers show concern & $81.8 \%$ & $18.2 \%$ & 11 & & \\
\hline Availability of drugs & $58.3 \%$ & $41.7 \%$ & 12 & & \\
\hline It is free & $45.8 \%$ & $54.2 \%$ & 24 & & \\
\hline Sources of knowledge about treatment & Male $(\mathrm{N}=76)$ & Female $(\mathrm{N}=101)$ & Total $(\mathrm{N}=177)$ & Statistics & $P$ value \\
\hline People recommend it for me & $36.9 \%$ & $63.1 \%$ & 149 & & \multirow{3}{*}{0.000} \\
\hline Heard from radio & $82.4 \%$ & $17.6 \%$ & 17 & \multirow[t]{2}{*}{$X^{2}=14.91$} & \\
\hline Saw it on bill board & $63.6 \%$ & $36.4 \%$ & 11 & & \\
\hline Means of raising funds for treatment & Male $(\mathrm{N}=76)$ & Female $(\mathrm{N}=101)$ & Total $(\mathrm{N}=177)$ & Statistics & $P$ value \\
\hline Through begging & $20.9 \%$ & $79.1 \%$ & 67 & \multirow{4}{*}{$X^{2}=24.61$} & \multirow{4}{*}{0.000} \\
\hline Manual labour with spouse & $28.6 \%$ & $71.4 \%$ & 7 & & \\
\hline Through my main trade & $60.8 \%$ & $39.2 \%$ & 79 & & \\
\hline Support from someone & $50.0 \%$ & $50.0 \%$ & 24 & & \\
\hline
\end{tabular}
$(\mathrm{P}<0.05)$.

Table 8. Health-seeking behavior factors associated with country of beggars.

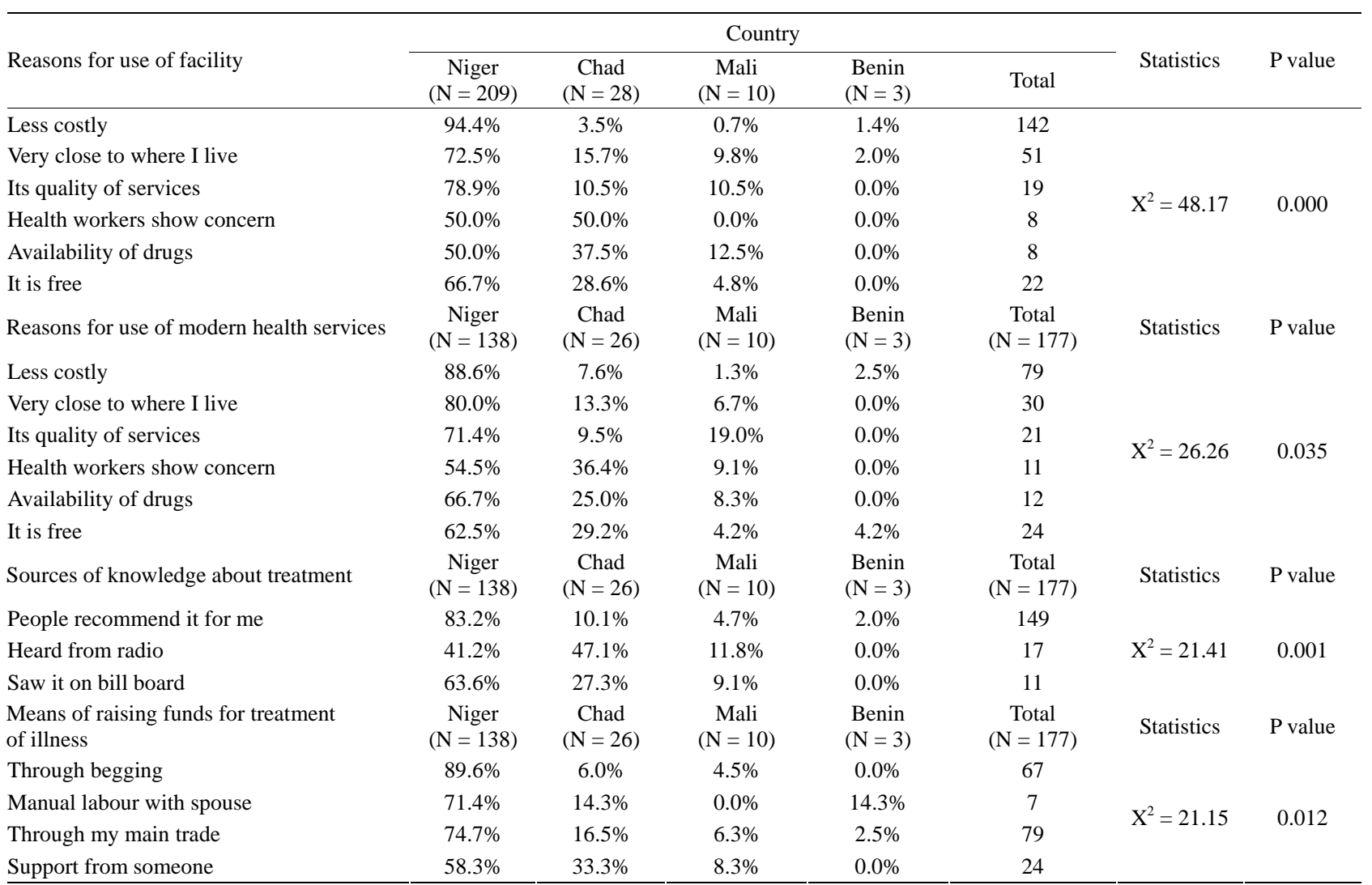
$(\mathrm{P}<0.05)$. 
association with migrant beggars' home country ( $\mathrm{P}<$ $0.05)$.

\section{DISCUSSION}

Studies have addressed the issue of begging in a global perspective [6,29,30,38,39] and identified domestic and cyber beggars in Nigeria [4,31,34], this study has however, identified migrant beggars as another category of beggars in Nigeria. More than half (56\%) the population of migrant beggars in this study was female. This sex proportion is slightly more than what Ogunkan and Fawole [4] documented. In their study that focused on domestic beggars [4], more of male beggars than female were identified (62.4\% male vs $37.6 \%$ female). The need for economic survival and zeal to support husband in home needs may be a factor for high number of women in the begging activities in this study. Studies on migration have confirmed that almost 3\% of the world's populations are migrants and that about half of these are women [40,41]. The results of Nigeria migration and urbanization survey 1993 show that $51.1 \%$ of migrants are females [41]. Globally, the proportion of female migrants has been rapidly increasing, rising from 41 million in 1975 to 95 million in 2005 [40]. Respondents in this study reportedly arrived Nigeria and their destination within the time frame noted by Bourguigon [40].

This study shows that the common health problem among a significant number of the migrant beggars was malaria, both in Nigeria (44.4\%) and their home countries (40\%). Some respondents had typhoid (26.8\%) in Nigeria and in their home countries (24.8\%). These illnesses could respectively be attributed to mosquito bite and consumption of unhygienic/contaminated water in the environment where they live. Such situation was possible [14] where war, civil disturbances or natural disasters lead to mass displacement of people from malaria epidemic areas to another malaria epidemic location, epidemics affecting the population at large breaks out. Nigeria shares border with home countries of beggars in this study hence a potential of such disease incidence due to population movements of various groups during peaceful times [42,43] and time of civil disturbance or natural disaster [14]. Exposure to causative factors of illness affects its rates. The illnesses generated in this study were basically those related to tropical diseases, while illness related to reproductive health were not mentioned. However, a previous study confirmed that farm workers who were migrants are agents of transmission of reproductive health problem in Southwestern Nigeria [44]. This study has found international migrant beggars as potential agents of disease transmission from their home countries to the host country. Reproductive health problem like HIV/AIDS is a potential disease of transmission and should be explored.

Nearly all the international migrant beggars were aware of the healthcare services available in Nigeria such as "chemist”, "health center", "faith healers", and "traditional healers". More than half (51.2\%) of the respondents used "chemist"/PMV services, compare to 39.2\% of them who utilised health center, $6.8 \%$ who used traditional healers and $0.8 \%$ who utilized faith healers. Previous studies [45-47] have reported availability of PMV and their potential strength in drug dispensation in rural and urban communities in Nigeria. The financial resources in respondents' possessions determine the type of health care services and treatment utilised within the facilities. Cost of treatment was a major factor in the determinant of utilization of healthcare services. Large majority of beggars were said to receive treatment from orthodox facility (70.8\%) than indigenous healers (6.8\%). The cost of such treatment was cheaper in the orthodox (N374.00) than the indigenous (N406.00). This study shows that respondents' preference for "chemist”/PMV to other health care services could be a result of the access (proximity and less costly) and the lack of access to health education programmes. Specifically, findings here show that not all the beggars in this study were fully accessible to health information. The lack of information may have faulty influence on the individual's perception of social environment [48]. The role of social network should be promoted to cater for certain behavior among the migrant beggars. While improved social network could be dynamic by race and gender for migrant beggars, identification of such approach could be utilised to trace people with chronic illness and for determining the influence of social group in disclosure of illness and choice of treatment.

The dynamics of consequences of migration involving this category of groups is the fundamentally devastating social change that may likely occur in the future. As economic push was the main reason that brought beggars to the fore, they could be susceptible to abuses if mobilised with money. Erinosho [49] noted the susceptibility of Almajiri (beggars who are Arabic learners in northern Nigeria) to all forms of abuses (which may include sexual abuse), infectious diseases and substance abuse. Although this study did not document any portend of addictive substance/abuse among the international migrant beggars; it is a pointer to areas of caution. One quick lesson from Erinosho's [49] observation is that beggars including international migrants, should be monitored and prevented from involving in such substance abuse as it may serve as catalyst for those who can mobilise them with money (their mainstay in the host country) to cause mayhem such as those in political upheavals. A study has documented a correlation between crisis period and transmission of disease [50]. This is cautionary that if 
adequate monitoring and regular screening is not in place, disease transmission might be a long term effect as noted in a previous study [44].

A major limitation in this study was language barrier. While effort was intensified to reduce challenges, the one faced through language may have affected some interpretation of responses and need to be pointed out for future studies to consider. This study traced participants from about fourteen major tribes in four neighbouring countries, hence, reaching a common language ground was challenging. However, majority of respondents spoke "pidgin" English, which was helpful in places where there was no one to interpret responses.

In conclusion, this study suggested the need for enhancement of healthcare services for varied categories/ groups of people including the beggars-both domestic and migrant. The role of social workers is significant in the rehabilitation of beggars hence social workers should be empowered to organise programs that could result in community re-integration to enhance beggars' capacity. Efforts such as the creation of rehabilitation centers for beggars [51] should be enhanced, replicated and monitored carefully. This may reduce the population of beggars on the roads. Immigration unit of the nation should be strengthened for proper documentation of arrival of foreigners. This should include data about their main health and social conditions for relevance in health and social policy formulation.

\section{REFERENCES}

[1] CSDH (2008) Closing the gap in a generation: Health equity through action on the social determinants of health. Final Report of the Commission on Social Determinants of Health, World Health Organization, Geneva.

[2] Bass, J.G. (2006) What really causes civil war? The New York Times, 17 December 2006.

[3] Bates, I., Fenton, C., Gruber, J., Lalloo, D., Medina Lara, A. and Squire, S.B. (2004) Vulnerability to malaria, tuberculosis, and HIV/AIDS infection and disease. Part I: Determinants operating at individual and household level. The Lancet Infectious Diseases, 4, 267-277. doi:10.1016/S1473-3099(04)01002-3

[4] Ogunkan, D.V. and Fawole, O.A. (2009) Incidence and socio-economic dimensions of begging in Nigeria cities: The case of Ogbomoso. International NGO Journal, 4, 498-503.

[5] Kassah, A.K. (1998) Community-based rehabilitation and stigma management by physically disabled people in Ghana. Disability and Rehabilitation, 20, 66-73. doi:10.3109/09638289809166056

[6] Pfaltzgraff, R.E. (2003) Begging as a profession and dehabilitation among leprosy patients. Leprosy Review, 74, 280-281.

[7] Castro, R.E.J. and Leya, R. (2007) Globalización y enfermedades infecciosas en las poblaciones indígenas de
México. Cadernos de Saúde Pública, 23, S41-S50. doi:10.1590/S0102-311X2007001300006

[8] Regassa, R. and Yusuffe, A. (2009) Gender differentials in migration impact in southern Ethiopia. Anthropologist, 11, 129-137.

[9] Oyewumi, O. (1997) The invention of women: Making an African sense of western gender discourses. University of Minnesota Press, Minneapolis.

[10] Matory, J.L. (1994) Gender and the politics of metaphor: Sex and the empire that is no more in Oyo Yoruba religion. University of Minnesota Press, Minneapolis.

[11] Coimbra, C.E. and Basta, P.C. (2007) The burden of tuberculosis in indigenous peoples in Amazonia, Brazil. Royal Society of Tropical Medicine and Hygiene, 101, 635636. doi:10.1016/j.trstmh.2007.03.013

[12] Hawker, J.I., Bakhshi, S.S., Ali, S. and Cp, F. (1999) Ecological analysis of ethnic differences in relation between tuberculosis and poverty. British Medical Journal, 319, 1031-1034. doi:10.1136/bmj.319.7216.1031

[13] Diaz De Quijano, E., Brugal, M.T., Pasarin, M.I., GaldosTanguis, H., Cayla, J. and Borrell, C. (2001) Influencia de las desigualdades sociales, la conflictividad social y la pobreza extrema sobre la morbilidad por tuberculosis en la ciudad de Barcelona. Revista Española de Salud Pública, 75, 517-528. doi:10.1590/S1135-57272001000600004

[14] Allen, R. (2001) Parasites and guns: Waging war against malaria. African Health (Medicine Digest), 24, 12-13.

[15] Arroyo, J., Saavedra, C., Cueto, M., Murillo, P. and Vidal, E. (2001) Interculturalidad en la atención de la salud. Estudio socioantropologico de enfermedades que cursan con síndrome ictero hemorrágico en ayacucho y cusco. Ministerio De Salud, Lima.

[16] Faura, T., Garcia, F., Isla, P., Lopez, C., Robau, M., Moreno, A. and Tricas, A. (2007) Problemas de salud y la vulnerabilidad social en pacientes inmigrantes ingresados con patologia infecciosa: Estudio caso-control. Revista Clínica Española, 207, 234-239. doi:10.1157/13102315

[17] Derose, K.P. and Escarce, J.J. (2007) Inmigrants and health care: Sources of vulnerability. Health Affairs, 26, 1258-1268. doi:10.1377/hlthaff.26.5.1258

[18] Zhang, T., Tang, S., Jun, G. and Whitehead, M. (2007) Persistent problems of access to appropriate, affordable Tb services in rural China: Experiences of different socioeconomic groups. BMC Public Health, 7, 19. doi:10.1186/1471-2458-7-19

[19] Cambanis, A., Yassin, M.A., Ramsay, A., Bertel Squire, S., Arbide, I. and Cuevas, L.E. (2005) Rural poverty and delayed presentation to tuberculosis services in Ethiopia. Tropical Medicine \& International Health, 10, 330-335. doi:10.1111/j.1365-3156.2005.01393.x

[20] Santha, T., Renu, G., Frieden, T.R., Subramani, R., Gopi, P.G., Chandrasekaran, V., Selvakumar, N., Thomas, A., Rajeswari, R., Balasubramanian, R., Kolappan, C. and Narayanan, P.R. (2003) Are community surveys to detect tuberculosis in high prevalence areas useful? Results of a comparative study from Tiruvallur District, South India. International Journal of Tuberculosis \& Lung Disease, 7, 
258-265.

[21] Bhatia, S., Dranyi, T. and Rowley, D. (2002) A social and demographic study of Tibetan refugees in India. Social Science and Medicine, 54, 411-422.

doi:10.1016/S0277-9536(01)00040-5

[22] Kirwan, D.E., Nicholson, B.D., Baral, S.C. and Newell, J.N. (2009) The social reality of migrant men with tuberculosis in Kathmandu: Implications for DOT in practice. Tropical Medicine \& International Health, 14, 14421447. doi:10.1111/j.1365-3156.2009.02405.x

[23] Udo, R.K. (1997) Migration and Urbanisation in Nigeria. Nigeria Migration and Urbanization Survey, 2003 NISER, Ibadan.

[24] Afolayan, A.A., Ikwuyatum, G.O. and Abejide, O. (2008) Dynamics of international migration in Nigeria. African Perspectives on Human Mobility Programme, MacArthur Foundation.

[25] Botto-Abella, C. and Graterol-Mendoza, B. (2007) Globalización, desigualdad y transmisión de enfermedades tropicales en el amazonas venezolano. Cadernos de Saúde Pública, 23, S51-S63. doi:10.1590/S0102-311X2007001300007

[26] Cabezas, C., Suarez, M., Romero, G., Carrillo, C., García, M.P. and Reátegui, J. (2006) Hiperendemicidad de hepatitis viral b y delta en pueblos indígenas de la amazonía peruana. Revista Peruana de Medicina Experimental y Salud Pública, 23, 114-122.

[27] Grenfell, P., Fanello, C.I., Magris, M., Goncalves, J., Metzger, W.G., Vivas-Martinez, Curtis, C. and Vivas, L. (2008) Anaemia and malaria in Yanomami communities with differing access to healthcare. Royal Society of Tropical Medicine and Hygiene, 102, 645-652. doi:10.1016/j.trstmh.2008.02.021

[28] Daniel, S.O. (1977) Social studies of the destitudes (beggars) in Nigeria: Lagos experience. Journal of Tropical Medicine \& Hygiene, 80, 156-168.

[29] Adedibu, A.A. (1989) Begging and poverty in Third World Cities: A case study of Ilorin, Nigeria. Ilorin Journal of Business and Social Science, 1, 25-40.

[30] Smith, R.C. (2005) Mexican New York: Transnational lives of new immigrants. University of California Press, Berkeley.

[31] Ogunkan, D.V. (2009) Socio-economic implication of begging in Ogbomoso, Nigeria. Unpublished Master Thesis, University of Ilorin, Ilorin.

[32] Ogunkan, D.V. (2011) Begging and almsgiving in Nigeria: The Islamic perspective. International Journal of Sociology and Anthropology, 3, 127-131.

[33] Ribadu, D.Y. and Mahmoud, A.O. (2010) Assessment of interrelationship between poverty and blindness in Maiduguri, Nigeria. Nigerian Postgraduate Medical Journal, 17, 308-312.

[34] Jelili, M.O. (2006) Environmental and socio-economic dimensions of begging in Ilorin and Ogbomoso. Unpublished Master Thesis, Ladoke Akintola University, Ogbomoso.

[35] Rosenstock, I.M. (1974) Historical origin of the health belief model. Health Education Monographs, 2, 238.
[36] Rosenstock, I.M. (1966) Why people use health services. Milbank Memorial Fund Quarterly, 44, 94-124. doi:10.2307/3348967

[37] Janz, N.K. and Becker, M.H. (1984) The health belief model: A decade later. Health Education Quarterly, 11, 1-47. doi:10.1177/109019818401100101

[38] D’Hondt, W. and Vandewiele, M. (1984) Beggary in West Africa. Journal of Adolescence, 7, 59-72. doi:10.1016/0140-1971(84)90048-4

[39] Kudrati, M., Plummer, M.L. and Yousif, N.D. (2008) Children of the sug: A study of the daily lives of street children in Khartoum, Sudan, with intervention recommendations. Child Abuse \& Neglect, 32, 439-448. doi:10.1016/j.chiabu.2007.07.009

[40] Bourguigon, F.J. (2006) Women on the move: Magnitudes, trends and impacts of international migration of women. United Nations, New York.

[41] NISER (1997) Nigerian migration and urbanization survey 1993. NISER, Ibadan.

[42] Mullany, L.C. (2007) Population-based survey methods to quantify associations between human right violations and health outcomes among internally displaced persons in Eastern Burma. Journal of Epidemiology \& Community Health, 61, 908-914. doi:10.1136/jech.2006.055087

[43] Beyrer, C. and Lee, T.J. (2008) Responding to infections in burma and her border regions. Conflict and Health, 2, 1-3. doi:10.1186/1752-1505-2-2

[44] Oyadoke, A.A., Brieger, W.R., Adesope, A. and Salami, K.K. (2003-2004) Migrant farm workers in Southwestern Nigeria: Implications for HIV transmission. International Quarterly of Community Health Education, 22, 247-266. doi:10.2190/RC0L-D0W5-P1FT-VV1X

[45] Oshiname, F.O. and Brieger, W.R. (1992) Primary care training for patent medicine vendors in rural Nigeria. Social Science and Medicine, 35, 1477-1484. doi:10.1016/0277-9536(92)90050-Z

[46] Brieger, W.R., Salami, K.K. and Oshiname, F.O. (2007) Perceptions of drug color among drug sellers and consumers in rural Southwestern Nigeria. Research in Social and Administrative Pharmacy, 3, 303-319. doi:10.1016/j.sapharm.2006.10.004

[47] Brieger, W.R., Osamor, P.E., Salami, K.K., Oladepo, O. and Otusanya, S.A. (2004) Observations of interaction between patent medicine vendors and customers in urban and rural Nigeria. Health Policy and Planning, 19, $177-$ 182. doi:10.1093/heapol/czh021

[48] Norman, P. and Conner, M. (1996) The role of social cognition models in predicting health behaviours: Future directions. In: Conner, M. and Norman, P., Eds., Predicting Health Behaviours: Research and Practice with Social Cognition Models, Open University Press, Buckingham, 197-225.

[49] Erinosho, O. (2011) Sociological explanation of insecurity in Nigeria: The Boko Haram phenomenon. Lecture Delivered at the Faculty of the Social Sciences, University of Ibadan, 18 August 2011 for the Nigerian Sociological and Anthropological Association (Students' chap- 
ter) of the University of Ibadan, 1-8.

[50] Jegede, A.S., Salami, K.K., Temilola, O.M. and Adejumo, P.O. (2004) Communal conflict and HIV/AIDS in Nigeria. African Journal for the Psychological Study of Social Is- sues, 7, 140-154.

[51] Okoli, C. (1993) The menace of organized street begging in Lagos, Nigeria. Newsletter 10, Disability Awareness in Action. 